Health and the Rise of Civilization 
This page intentionally left blank 
Mark Nathan Cohen

\section{Health and the}

\section{Rise of Civilization}

Yale University Press New Haven and London 
Published with assistance from the Louis Stern Memorial Fund.

Copyright (C) 1989 by Yale University.

All rights reserved.

This book may not be reproduced, in whole or in part, including illustrations, in

any form (beyond that copying permitted by Sections 107 and 108 of the U.S. Copyright Law and except by reviewers for the public press), without written permission from the publishers.

Library of Congress Cataloging-in-Publication Data

Cohen, Mark Nathan.

Health and the rise of civilization / Mark Nathan Cohen.

p. $\mathbf{c m}$.

Bibliography: $p$.

Includes index.

ISBN 978-0-300-05023-3 (pbk.)

1. Medical sociology. 2. Health. 3. Civilization. I. Title.

$\mathrm{RA}_{4} 18 . \mathrm{C}_{664} 1989$

$614.4-\mathrm{dc} 19$

89-5405

CIP

The paper in this book meets the guidelines for permanence and durability of the Committee on Production Guidelines for Book Longevity of the Council on Library Resources.

Printed in the United States of America 